Bawden, F. C. \& Nixon, H. L. (1951). J. gen. Microbiol. 5, 104-109.

\title{
The Application of Electron Microscopy to the Study of Plant Viruses in Unpurified Plant Extracts
}

\author{
By F. C. BAWDEN AND H. L. NIXON \\ Rothamsted Experimental Station, Harpenden, Hertfordshire
}

\begin{abstract}
SUMMARY: Rods of variable lengths occurred in sap from plants infected with tobacco mosaic, cucumber mosaic, potato $X$, potato $Y$, henbane mosaic, tobacco etch, and cabbage blackring viruses; the first two were about $15 \mathrm{~m} \mu$. wide and appeared rigid, the others were about $10 \mathrm{~m} \mu$. wide and apparently flexible. Sap from plants infected with tomato bushy stunt, tobacco ringspot and two tobacco necrosis viruses contained spherical particles about $26 \mathrm{~m} \mu$. in diameter; two particles, one about $18 \mathrm{~m} \mu$. and the other about $37 \mathrm{~m} \mu$. in diameter occurred in sap from plants infected with a third tobacco necrosis virus. No specific particles were identified in sap from plants infected with tomato spotted wilt, potato leaf roll, cauliflower mosaic, tomato aspermy, sugar beet mosaic and sugar beet yellows viruses. Serologically related strains of any one virus were morphologically indistinguishable, but this has little diagnostic value because so also were some unrelated viruses.
\end{abstract}

Electron microscopy has so far been mainly restricted to the study of purified plant viruses, for which there are alternative methods of assessing particle size. Since the development of the shadow-casting technique (Müller, 1942; Williams \& Wyckoff, 1944), there has been no difficulty in detecting particles of such viruses as tobacco mosaic, potato $X$ and tomato bushy stunt in clarified infective sap, but there has been no systematic attempt to apply the technique to less stable viruses about whose sizes and shapes little is known. The work described in this paper was begun to see whether electron microscopy was generally applicable to unpurified preparations of plant viruses and to assess its value for identification purposes.

\section{MATERIALS AND METHODS}

The following virus-host combinations have been studied; tobacco mosaic, potato virus $X$, potato virus $Y$, tomato spotted wilt, tomato aspermy (Blencowe \& Caldwell, 1949), henbane mosaic, cucumber mosaic, tobacco etch and the tobacco necrosis viruses in tobacco (Nicotiana tabacum), var. White Burley; tomato bushy stunt, tomato spotted wilt and potato paracrinkle in tomato (Lycopersicum esculentum), var. Kondine Red; cauliflower mosaic and cabbage blackring in turnip (Brassica napus); cabbage blackring in Nicotiana glutinosa; sugar beet mosaic and sugar beet yellows in sugar beet (Beta vulgaris); potato leaf roll and potato paracrinkle in potato (Solanum tuberosum), several varieties; potato leaf roll in Datura stramonium.

Various methods of making extracts from infected leaves were tried, of which the following gave the most generally satisfactory results. Leaves were picked when showing severe symptoms, and the bulk of the mid-ribs were cut out and discarded. The laminae were lightly dusted with $\mathrm{Na}_{2} \mathrm{HPO}_{4}$, ground with a pestle in a mortar and the sap expressed through muslin. After lying for some 
hours at $-10^{\circ}$, the sap was thawed, centrifuged for 10 min. at 7000 r.p.m. and the supernatant fluid used immediately for making specimens for electron microscopy. Samples of the fluid were also tested by inoculation to a suitable range of differential host plants to ensure their freedom from contaminating viruses. None was ever found, and we have no reason to think that our preparations contained any virus except the one named. Samples of clarified sap from uninfected plants of the same species were also made by the same method.

The mounts for electron microscopy were made by placing small drops of the clarified sap on collodion-covered specimen grids and removing the fluid after a minute with a micro-pipette. To remove salts, the mounts were dipped in distilled water, and dried on hard filter-paper. They were then shadowed with about $8 \mathrm{~A}$. thickness of palladium, which was cast at an angle of about 12 degrees from the plane of the mount. The electron microscope was an R.C.A. model B, fitted with a three-electrode gun, and was used with an accelerating potential of $50 \mathrm{kV}$.

\section{RESULTS}

The suitability of different species of plant for this kind of work varied widely, for whereas sap from some when mounted for electron microscopy contained little background material that interfered with the identification of possible virus particles, the sap from others contained much. Sap from solanaceous plants except the potato, after treating with phosphate and freezing, was more suitable than that from other species. Potato is particularly unsuitable, because sap from uninfected plants of all the varieties we have tried contains rod-like particles resembling those of some viruses (Bawden, Kassanis \& Nixon, 1950).

\section{Virus-host combinations with which no specific particles were identified}

Our results can conveniently be divided into two groups; the preparations of sap from infected plants in which we found no particles distinct from those that also occurred in similar preparations from healthy plants, and those in which we found particles specific to the infected plants. The first group contains tomato spotted wilt, potato leaf roll, sugar beet mosaic, sugar beet yellows, cauliflower mosaic and tomato aspermy viruses. There is therefore still no information bearing on the size and shape of these virus particles. Failure to detect any particles that might be the viruses themselves may have different explanations with different virus-host combinations. With some, the virus content of sap is probably too small for the technique to be applicable. The limiting concentration for success depends on the shape of the particles and on the composition of the medium from which they are dried in making mounts for examination in the electron microscope. The rod-shaped particles of tobacco mosaic virus can be found without great difficulty when purified preparations are diluted in water to concentrations of $0.01 \mathrm{mg} . / 1$., and the spherical particles of tomato bushy stunt virus up to $0.01 \mathrm{mg}$./1. When diluted in clarified sap from healthy tobacco plants, however, and the mounts washed to free them from salts in the manner described, the limiting concentration at which 
tobacco mosaic virus particles are readily detected is about $1 \mathrm{mg} . / \mathrm{l}$. and tomato bushy stunt $10 \mathrm{mg}$./ $\mathrm{l}$. The effects of the mounting medium in increasing the limiting concentration are partly attributable to the removal of some virus particles when the mounts are washed with water, and partly to the fact that other materials in sap make it difficult to identify individual particles when they are widely separated. Individual particles of tobacco mosaic virus are more easily detected than those of tomato bushy stunt virus because elongated rods are more distinctive than spheres of comparable widths. This is especially so with clarified sap in which deposits of normal plant materials are more likely to obscure spheres than rods; also sap from uninfected plants of all species contain spherical particles resolvable by the electron microscope. From frozen sap of Nicotiana sp., tomato and turnip, these are smaller than particles of any of the viruses we have studied. Clarified sap from uninfected potato plants contains rod-like particles of unknown composition (Bawden et al. 1950), but we have seen none in the clarified frozen sap of any of the other species of uninfected plants we have examined.

A virus content of less than about $10 \mathrm{mg}$./l. if the particles are spherical and $1 \mathrm{mg} . / \mathrm{l}$. if they are rod-shaped, may explain our failure to detect specific particles in sap from plants infected with tomato spotted wilt, potato leaf roll, sugar-beet mosaic and cauliflower mosaic viruses, but this explanation is inadequate with sugar beet yellows. Clarified sap from infected sugar-beet leaves contains a specific antigen that precipitates with antiserum up to dilutions of $1 / 64$ (Kleczkowski \& Watson, 1944). The precipitate is of somatic type, resembling that given by viruses with spherical particles, and the precipitation end-point suggests a virus content in sap of more than $100 \mathrm{mg} . / \mathrm{l}$., similar to that reached by tomato bushy stunt virus. The antigen sediments in centrifuge fields of $30,000 \mathrm{~g}$ and so should be amply large to be resolved in the electron microscope. Our failure to identify any particles that might be sugar-beet yellows virus probably means that the virus has spherical particles of a similar size to those that occur in normal sugar-beet leaves. Unlike electron micrographs of clarified sap from the solanaceous plants we have examined, those of sap from uninfected sugar beet give a field covered thickly with spherical particles about $10 \mathrm{~m} \mu$. in diameter. Like the specific antigen from infected leaves, these particles sediment in the ultracentrifuge, and only by serological tests have differences yet been detected between sap from infected and healthy sugar beet plants. The quantities of large particles of normal components also may explain our failure to detect sugar beet mosaic virus; we have occasionally had suggestions that sap from infected plants contained rod-like particles, but these were too heavily overlain with other particles for any certain identification.

\section{Virus-host combinations containing specific particles}

In sap from plants infected with the other viruses, we have found particles that are absent from similar preparations made from uninfected plants. These are assumed to be the virus particles, and we shall refer to them as such, but in the absence of any proof of their infectivity, it must be stressed that this is an 
assumption and that their identity remains unestablished. Several strains of potato virus $X$ have been found to have rod-like tenuous particles about $10 \mathrm{~m} \mu$. wide and of greatly variable lengths. The manner in which these aggregate to form extensive rod- and net-like structures has been described by Kleczkowski \& Nixon (1950). Three strains of potato virus $Y$, namely, our stock virulent culture, (Pl. 1, fig. 1) potato virus $C$ (PI. 1, fig. 2) (Bawden \& Kassanis, 1947) and tobacco veinal necrosis virus (Pl. 1, fig. 3) (Smith \& Dennis, 1940), which are serologically related but cause widely different diseases in different hosts, were also rod-like particles about $10 \mathrm{~m} \mu$. wide and variable lengths. They also appeared to resemble potato virus $X$ in being tenuous, capable of linear aggregation and becoming intertwined, (Pl. 1, fig. 2) but the concentration of these particles was much smaller than with potato virus $X$, and the phenomenon has not been studied in any detail. The results are in keeping with those from attempts to purify this virus, which showed that concentrated preparations gave the phenomenon of anisotropy of flow and that the virus occurred at about one-fiftieth of the concentration of potato virus $X$ (Bawden \& Pirie, 1939). Particles similar to those of potato virus $Y$, and occurring in similar quantities, were also found in sap from plants infected with potato paracrinkle, two strains of henbane mosaic, tobacco etch, and cabbage blackring viruses. It is probable that our cabbage blackring virus is similar to the Brassica nigra virus described by Takahashi (1949). In sap from plants infected separately with two different strains of cucumber mosaic virus, rod-like particles were also found, but these differed slightly from those already described. They were again of variable lengths, but resembled those of tobacco mosaic virus in being about $15 \mathrm{~m} \mu$. wide, and in having an appearance of rigidity that contrasts with the seeming flexibility of those with narrower particles. They occurred in numbers comparable to those found in sap from tobacco mosaic plants diluted about $1 / 1000$, and there is also a factor of this order between the dilution end points at which sap from tobacco plants infected with the two viruses ceases to cause infections in tobacco.

The other viruses we have studied all appear to have spherical particles, which, except for tobacco ringspot virus, is in keeping with what is known of their physical properties and serological behaviour. Tobacco ringspot, from studies of physical properties of purified preparations, has been variously stated to have rod-shaped particles $183 \mathrm{~m} \mu$. long and $10 \cdot 4 \mathrm{~m} \mu$. wide (Stanley, 1938) and a spherical particle of diameter $19 \mathrm{~m} \mu$. (Stanley, 1939); our results suggest a spherical particle with diameter about $26 \mathrm{~m} \mu$. (Pl. 2, fig. 9). This is similar to the size of tomato bushy stunt virus (Pl. 2, fig. 14) and also to the tobacco necrosis viruses which Bawden \& Pirie (1942) called tobacco II, tobacco VI and potato (Pl. 2, figs. 11-13). These three all have the same sedimentation constant. The two last are related strains but are serologically unrelated to the first. No cultures of these viruses are now maintained, and our pictures were made from clarified sap that had been kept in the refrigerator for more than 5 years. The sap was not infective but was still serologically active. The particles are less well defined than those of the spherical viruses examined in fresh sap, and it may be that they had been denatured by ageing. Sap from tobacco 
leaves infected with the Rothamsted tobacco necrosis virus differed from any other in that it contained specific spherical particles of two sizes; one is about $18 \mathrm{~m} \mu$. and the other about $37 \mathrm{~m} \mu$. in diameter. In the plate (Pl. 2, fig. 10) we show a micrograph of a partially purified preparation of this virus because our pictures of these particles in clarified sap are unsuitable for reproduction. These two sizes presumably correspond to those shown by Ogston (1942) to have sedimentation constants of 240 and $51 \mathrm{~S}$. Particles of similar sizes occur in sap from plants infected with bean stipple-streak virus, which is serologically related to the Rothamsted tobacco necrosis virus (Bawden \& van der Want, 1949). The possible relationships between these two particles have been discussed by Bawden \& Pirie (1950).

\section{MORPHOLOGY AND CLASSIFICATION}

Our results show that by applying the technique of shadow casting to mounts of clarified infective sap, electron microscopy can be used to determine the approximate sizes and shapes of the particles of some plant viruses that are insufficiently stable and occur at too high dilutions to be readily purified. It is unlikely to be applicable to all viruses, but by modifications of our technique, for example, by better methods of washing the mounts or by using methods of clarifying infective sap that remove more of the normal plant components but not the virus particles, it may be extended to many more and probably to some with which we have so far failed. The fact that clinically distinct viruses, which are now grouped as strains because they are serologically related, and mutually antagonistic when present together in infected plants, have particles of the same size and shape suggests, at first sight, that electron microscopy may be valuable in classifying viruses. However, many serologically unrelated viruses with widely differing general properties have appeared to be indistinguishable morphologically, and, as with ordinary microscopy and bacteria, the value of electron microscopy seems likely to be restricted to dividing plant viruses into a number of broad groups. Consistent differences in particle size and shape between viruses will be useful and will help to distinguish between clinically similar types, but the fact that two viruses have particles of the same size and shape is no evidence of relationship.

\section{REFERENCES}

Bawden, F. C. \& Kassanis, B. (1947). The behaviour of some naturally occurring strains of potato virus Y. Ann. appl. Biol. 34, 503.

Bawden, F. C., Kassanis, B. \& Nixon, H. L. (1950). The mechanical transmission and some properties of potato paracrinkle virus. J. gen. Microbiol. 4, 210.

Bawden, F. C. \& Pirie, N. W. (1939). The purification of insect-transmitted plant viruses. Brit. J. exp. Path. $20,322$.

Bawden, F. C. \& Pirie, N. W. (1942). A preliminary description of preparations of some of the viruses causing tobacco necrosis. Brit. J. exp. Path. 23, 314.

Bawden, F. C. \& Pirie, N. W. (1950). Some factors affecting the activation of virus preparations made from tobacco leaves infected with a tobacco necrosis virus. J. gen. Microbiol. 4, 464.

Bawden, F. C. \& van der Want, J. P. H. (1949). Bean-stipple-streak caused by a tobacco necrosis virus. Tijdschr. PlZiekt. 55, 142. 
Journal of General Microbiology, Vol. 5, No. 1
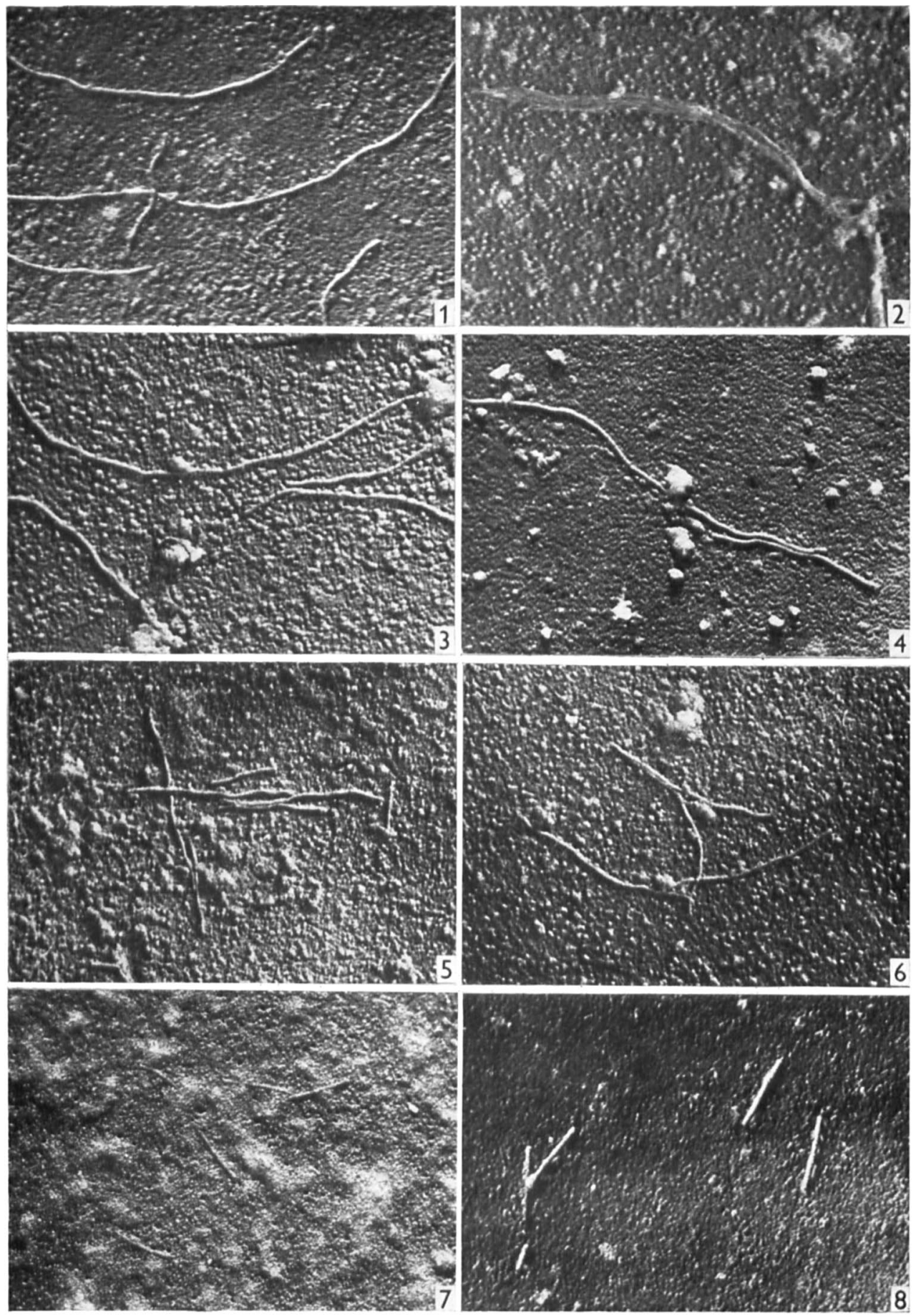

Figs. 1-8

F. C. Bawden and H. L. Nixon-Electron microscopy of unpurified viruses. Plate 1 
Journal of General Microbiology, Vol. 5, No. 1
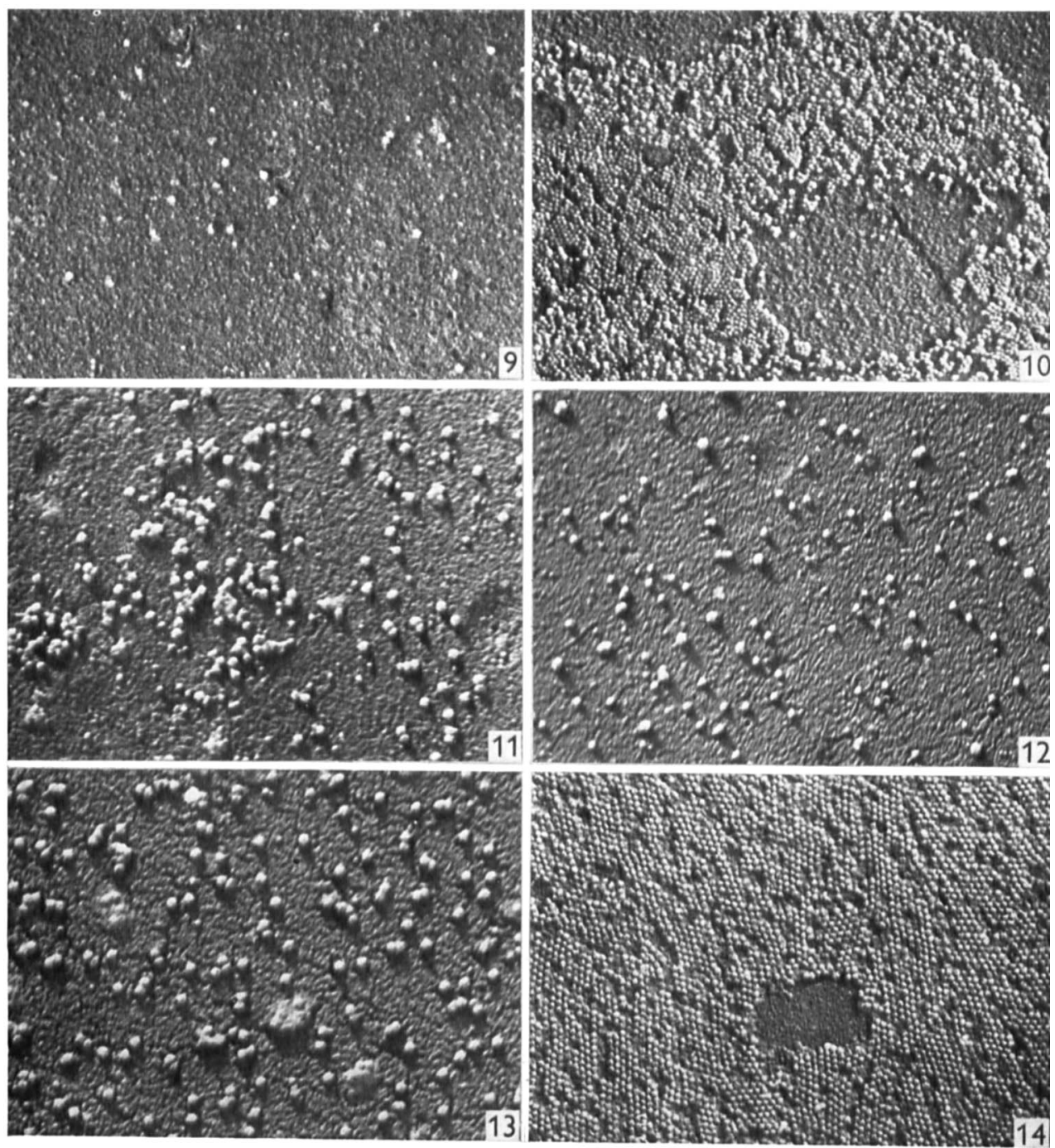

Figs. 9-14

F. C. Bawden and H. L. Nixon-Electron microscopy of unpurified viruses. Plate 2 
Blencowe, J. W. \& Caldwell, J. (1949). Aspermy-a new virus disease of the tomato. Ann. appl. Biol. 36, 320.

Kleczkowski, A. \& Nixon, H. L. (1950). An electron microscope study of potato virus $X$ in different states of aggregation. J. gen. Microbiol. 4, 220.

KLeczkowski, A. \& Watson, M. A. (1944). Serological studies of sugar-beet yellows virus. Ann. appl. Biol. 31, 116.

MüLLER, H. O. (1942). Measurement of the depth of electron microscopic objects. Kolloidzschr. 99, 6.

Ogston, A. G. (1942). Examination in the ultracentrifuge. Brit. J. exp. Path. 23, 328.

Smith, K. M. \& Dennis, R. W. G. (1940). Some notes on a suspected variant of Solanum virus 2 (Potato virus Y). Ann. appl. Biol. 27, 65.

Stanley, W. M. (1938). Biochemistry and biophysies of viruses. Handbuch der Virusforschung, Part 1, ed. by Doerr, R. \& Hallauer, C. p. 447. Vienna: Julius Springer.

Stanley, W. M. (1939). The isolation and properties of tobacco ringspot virus. J. biol. Chem. 129, 405 .

Takahashi, W. N. (1949). The morphology and host range of Brassica nigra virus. Amer. J. Bot. 36, 534.

Williams, R. C. \& Wyckoff, R. W. G. (1944). Thickness of electron microscopic objects. J. appl. Physics, 15, 712.

\section{EXPLANATION OF PLATES}

All mounts were made from clarified sap unless otherwise stated, and all were shadowed with about $8 \mathrm{~A}$. of palladium. The final magnification has been adjusted in the photographic work to $\times 30,000$.

Fig. 1. Potato virus $Y$ in tobacco.

\section{Plate 1}

Fig. 2. Potato virus $C$ (serologically related to potato virus $Y$ ) in tobacco.

Fig. 3. Tobacco veinal necrosis virus (serologically related to potato virus $Y$ ) in tobacco.

Fig. 4. Severe etch virus in tobacco.

Fig. 5. Cabbage blackring virus in turnip.

Fig. 6. Henbane mosaic virus in tobacco.

Fig. 7. Cucumber mosaic virus (strain causing a bright yellow mottle) in tobacco.

Fig. 8. Cucumber mosaic virus (strain causing severe necrosis) in tobacco.

Plate 2

Fig. 9. Tobacco ringspot virus in tobaceo.

Fig. 10. Tobacco necrosis virus (Rothamsted culture) mount from virus preparation which had been partially purified with the ultracentrifuge.

Fig. 11. Tobacco necrosis virus, tobaceo II culture of Bawden \& Pirie (1942).

Fig. 12. Tobacco necrosis virus, potato culture of Bawden \& Pirie (1942).

Fig. 13. Tobacco necrosis virus, tobacco VI culture of Bawden \& Pirie (1942).

Fig. 14. Tomato bushy stunt virus, mount from partially purified preparation.

(Received 1 April 1950) 